\title{
The effect of different diets including those containing soya-bean products, on digesta movement and water and nitrogen absorption in the small intestine of the pre-ruminant calf
}

\author{
By J. W. SISSONS AND R. H. SMITH \\ National Institute for Research in Dairying, \\ Shinfield, Reading $R G 29 A T$ \\ (Received 3 December 1975 - Accepted 9 February 1976)
}

\begin{abstract}
I. Preruminant calves, fistulated in the abomasum and distal ileum, were given by infusion into the abomasum, at intervals of $2-3 \mathrm{~d}$, single experimental feeds of cow's milk or a synthetic milk diet in which the protein source was casein or a soya-bean product. Polyethylene glycol (PEG) and phenol red were included as markers.

2. After infusion of the experimental feed, measurements were made of transit time from proximal duodenum to distal ileum and mean ileal flow-rates for the first 3 and $2 \mathrm{~h}$ after food residues reached the distal ileum. PEG recoveries for these two periods and net nitrogen absorption up to the distal ileum were also determined. In some experiments sodium, potassium and magnesium concentrations and numbers of viable bacteria in ileal digesta were determined.

3. Measurements of passage of digesta, recovery of marker and net $\mathbf{N}$ absorption did not differ greatly between calves given cow's milk and the synthetic milk diet containing casein. Compared to the casein-based diet, a diet based on heated soya-bean flour given to a calf for the first or second time produced a somewhat higher ileal flow-rate and a significantly lower net $\mathrm{N}$ absorption. Net $\mathrm{N}$ absorption was even lower when a calf received a diet containing unheated soya-bean flour.

4. Calves given the diet containing heated soya-bean flour on several occasions appeared to develop a sensitivity to the flour, and after further feeds containing it they had significantly higher rates of ileal flow (accompanied by correspondingly high rates of $\mathrm{Na}$ and $\mathrm{K}$ flow), lower small intestine transit times and lower net $\mathrm{N}$ absorption values than similarly fed unsensitized calves. They also had significantly lower rates of passage of marker in the first few hours after food residues reached the ileum, indicating inhibition of abomasal emptying. Over all, the changes indicated a severe disturbance in digestive function which was not caused by abnormal bacterial growth and may have been due to a gastrointestinal allergy.

5. Diets prepared from water-extracted flour and from soya-bean-protein isolate also led to digestive disturbances in sensitized calves, but those containing concentrates prepared by extracting soya-bean meal with hot aqueous ethanol did not.
\end{abstract}

A number of workers have studied the passage of digesta from the abomasum to the duodenum of the liquid-fed calf and the factors responsible for variations in this process (see Smith \& Sissons, 1975). It has been suggested that variations of this kind caused, for example, by giving a diet prepared from overheated dried skim milk (Tagari \& Roy, I969) or by including large proportions of heated soya-bean flour in the diet (Smith \& Sissons, 1975) may be associated with the poor performance and digestive disorders which often result from giving these diets. Movements of digesta in the small intestine, which are more likely to have a direct relation to nutrient utilization have, however, been little studied in the calf. Some studies of the movement of digesta through, and absorption of nutrients from, this part of the digestive tract have been made after feeds of cow's milk (Smith, I962, I964, I966; 
Mylrea, $1966 a, b$ ) but, apart from some results for digesta movement after simple solutions containing mainly minerals and glucose were given (Smith, 1964, 1966), little attention has been paid to the variations which might occur with other dietary components. The present work was undertaken to provide this information for synthetic milk diets in which the protein source was either casein or one of a number of soya-bean products.

\section{METHODS}

\section{Animals}

Friesian bull calves were each equipped with an abomasal cannula (Smith \& Sissons, 1975) and a re-entrant cannula in the ileum, less than $100 \mathrm{~mm}$ from the ileo-caecal junction. The ileal cannulas were moulded from flexible polyvinyl chloride (Ash, 1962) with an internal diameter of $12 \mathrm{~mm}$. Cannulas were inserted when the calves were $\mathrm{I}-6$ weeks of age and the animals were also castrated at this time.

From birth, the calves were given colostrum and then whole milk, supplemented from 3 weeks with minerals and vitamins (Smith \& Sissons, 1975). Supplements of aureomycin (Cyamamid Agricultural Division, Gosport, Hants) were added to each feed $\left(0^{\circ} \mathrm{g} / \mathrm{d}\right)$ from I week after the cannulation operation. The calves were kept on this feeding regimen and were fed by bucket except on days when digesta collections were made.

\section{Experimental diets}

Experiments were started 2 weeks after surgery when the calves were 5-9 weeks of age. Cow's milk or synthetic milk diets were given. The latter contained $(\mathrm{g} / \mathrm{kg}$ liquid diet): $\mathrm{NaOH} 0.85$, citric acid $0 \cdot 77, \mathrm{Na}_{2} \mathrm{HPO}_{4} 0 \cdot 42, \mathrm{~K}_{2} \mathrm{HPO}_{4} 2 \cdot 70, \mathrm{KH}_{2} \mathrm{PO}_{4}$ $0.58, \mathrm{CaCl}_{2} .6 \mathrm{H}_{2} \mathrm{O} 2.67, \mathrm{MgCl}_{2} .6 \mathrm{H}_{2} \mathrm{O} 0.94$ together with $\mathrm{I}_{4} \mathrm{~g}$ margarine (emulsified with $0.6 \mathrm{~g}$ Lubrol W (ICI Ltd, Manchester)), $32 \mathrm{~g}$ glucose and a protein source consisting of $42 \mathrm{~g}$ calcium caseinate or a suitable amount of a soya-bean product. The latter products, which have been described previously (Table I of Smith \& Sissons (I975)), consisted of lightly heated (product A) or fully heated (product B) soya-bean flour, or of concentrates prepared from soya-bean meal by extraction with aqueous ethanol at about $65^{\circ}$ (product $\mathrm{D}$ ) or with water (product $\mathrm{E}$ ). An isoelectric isolate of soya-bean protein (product $F$ ) or its sodium salt (product $G$ ) were also used. Amounts ( $\mathrm{g} / \mathrm{kg}$ liquid diet) of the soya-bean products added were: $\mathrm{A}$ and $\mathrm{B}$, $66 ; \mathrm{D}$ and $\mathrm{E}, 52 ; \mathrm{F}$ and $\mathrm{G}, 44$. The $\mathrm{pH}$ values of the synthetic diets were between 6.5 and 6.7 . Diets were given by infusion into the abomasum as single experimental feeds, at an average rate of $5^{\circ} \mathrm{g}$ liquid diet $/ \mathrm{kg}$ body-weight but absolute amounts were kept constant for any one group of collections from a single calf in which different diets were compared. Intakes therefore varied between 40 and $60 \mathrm{~g} / \mathrm{kg}$ body-weight. Experimental feeds were given at intervals of 2-3 $d$ for periods of up to $\mathrm{I} 3$ weeks.

\section{Digesta collections}

On collection days a calf was placed in a restraining crate at 08.30 hours having previously been acclimatized to this restraint, and its re-entrant cannula opened. At 09.30 hours an appropriate experimental feed, which did not contain aureomycin 
but always contained $5 \mathrm{~g}$ polyethylene glycol (PEG) (molecular weight 4000) and O. I $\mathrm{g}$ phenol red as markers was infused into the abomasum at a rate of about $300 \mathrm{ml} / \mathrm{min}$ (Smith \& Sissons, 1975). Samples of ileal digesta were collected and weighed until the first appearance of phenol red. The time between infusion and phenol red appearance was recorded as the transit time through the small intestine. From the time of phenol red appearance digesta were collected either in one sample up to $3 \mathrm{~h}$ and another sample from $3^{-2 \mathrm{I}} \mathrm{h}$, or automatically in approximately $5^{\circ} \mathrm{g}$ fractions up to $2 \mathrm{I} h$. The latter fractions were subsequently bulked into a $\mathrm{o}-3 \mathrm{~h}$ sample and a $3^{-2} \mathrm{r} h$ sample for analysis. No further feed was given during the collection period but water (about 31 ) was allowed at 17.30 hours.

Collections were made after giving experimental feeds of whole milk, diets prepared from casein or, for one calf, a diet prepared from product A. Further series of experimental feeds of the diet containing product $\mathrm{B}$ were then given and collection made after each. When four feeds of the latter diet had been given, changes in digesta flow became apparent and for some calves comparisons were subsequently made between diets containing this product and those containing other soya-bean products. In any one comparative experiment a group of up to three diets containing different products was studied and each set of comparisons was repeated at least once and usually more than this unless stated otherwise. A flow study made after giving an experimental feed of the casein-containing diet was also included in each group to provide a reference standard. Results were based on mean values obtained from the replicated sets of comparisons and are expressed to show variation between calves.

In these experiments ileal effluent was not returned to the distal cannula, as preliminary studies had indicated that return did not affect either the pattern or the over-all rate of passage of digesta from the proximal cannula. For example, mean $( \pm \mathrm{SE})$ rates of digesta flow $(\mathrm{g} / \mathrm{h})$ measured over a $6 \mathrm{~h}$ period after the appearance of phenol red in two series of experimental feeds with one calf given $4.4 \mathrm{~kg}$ milk were IOI \pm 3 and $90 \pm$ Io for return and non-return respectively; corresponding values for a series of three experimental feeds when $4.4 \mathrm{~kg}$ milk $+200 \mathrm{~g}$ sucrose were given were $600 \pm 30$ and $596 \pm 16$ respectively.

\section{Analytical methods}

Total nitrogen. Samples of homogenized digesta ( $\mathrm{I}$ g), liquid diet (I g) or dietary protein source (0.I g) were digested as described by Smith \& Sissons (1975) and the ammonia- $\mathrm{N}$ produced was estimated colorimetrically using an automated technique (Technicon Instruments Co. Ltd, 1967).

$P E G$. The amount of PEG in digesta samples was determined by the method described by Smith $(1958,1962)$ except that 20 min was allowed for the development of turbidity. Phenol red, when it was present, was first removed from the samples according to Smith (1964).

$\mathrm{Na}$ and potassium. The amounts of $\mathrm{Na}$ and $\mathrm{K}$ in digesta samples were measured by flame photometry (R. H. Smith, 1962).

Magnesium. The amount of $\mathrm{Mg}$ in digesta samples was determined by atomic absorption spectroscopy (Smith \& McAllan, r966). 


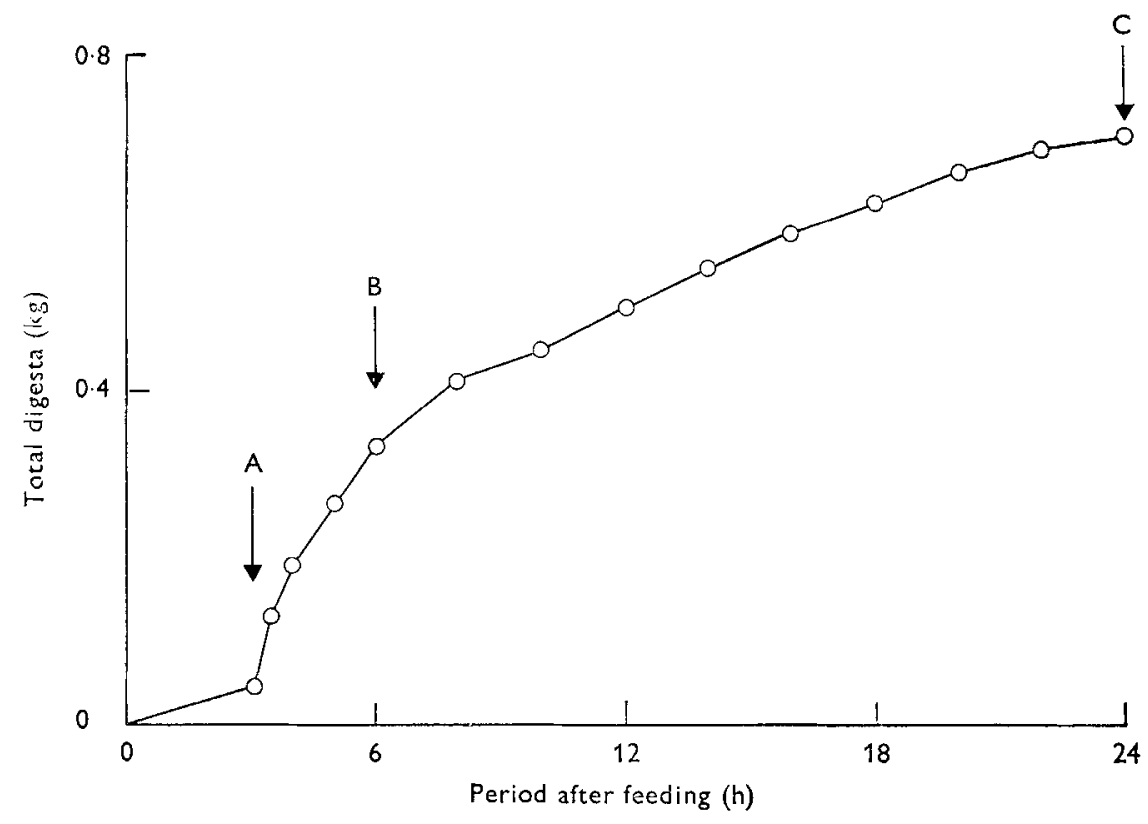

Fig. I. Cumulative amounts of digesta $(\mathrm{kg})$ leaving the distal ileum of a calf aged $80 \mathrm{~d}$ after it was given, by infusion, an experimental feed of $2.6 \mathrm{~kg}$ synthetic milk diet containing casein as the only protein source (for details see p. 422). Phenol red, which was included in the experimental feed, appeared at the ileum at time interval $A$ and this represented small intestine transit time; ileal flow measurements $(3$ and $2 \mathrm{rh}$ ) were made between time intervals $A$ and $B$, and $A$ and $C$ respectively.

\section{RESULTS}

Digesta flow and $N$ utilization after single experimental feeds of diets containing milk protein as the only protein source

The pattern of flow of digesta from the distal ileum of a calf, given by abomasal infusion a single experimental feed of the diet containing casein, after $18 \mathrm{~h}$ without food, is indicated by the results of a typical experiment shown in Fig. I.

From experiments such as this the following measurements were made: (a) transit time through the small intestine (SI transit time); (b) mean rates of digesta flow over the first 3 or $2 \mathrm{I} \mathrm{h}$ after food residues reached the ileum $(3$ or $2 \mathrm{I} h$ ileal flow respectively); (c) cumulative recoveries of dietary PEG up to 3 or $2 \mathrm{I} \mathrm{h}$ after food residues reached the ileum (3 or 2 I h PEG recovery respectively); $(d)$ net disappearance of $\mathrm{N}$ between mouth and ileum in a period of $24 \mathrm{~h}$ after a feed was given corrected to $100 \%$ PEG recovery (net $\mathrm{N}$ absorption):

$$
\text { i.e. net } \mathrm{N} \text { absorption }=\mathrm{I}-\frac{\text { ileal } \mathrm{N} \text { flow in } 24 \mathrm{~h}}{\text { dietary } \mathrm{N}} \times \frac{\text { dietary PEG }}{\text { ileal PEG flow in } 24 \mathrm{~h}} \text {. }
$$

For experiments in which experimental feeds of the casein-containing diet were given there were no significant differences in any of these measurements between calves varying in age from about 6 to 15 weeks, or between calves that had previously received different numbers of these feeds (Table $\mathrm{I}$ ). In other experiments in which 
Vol. $3^{6}$

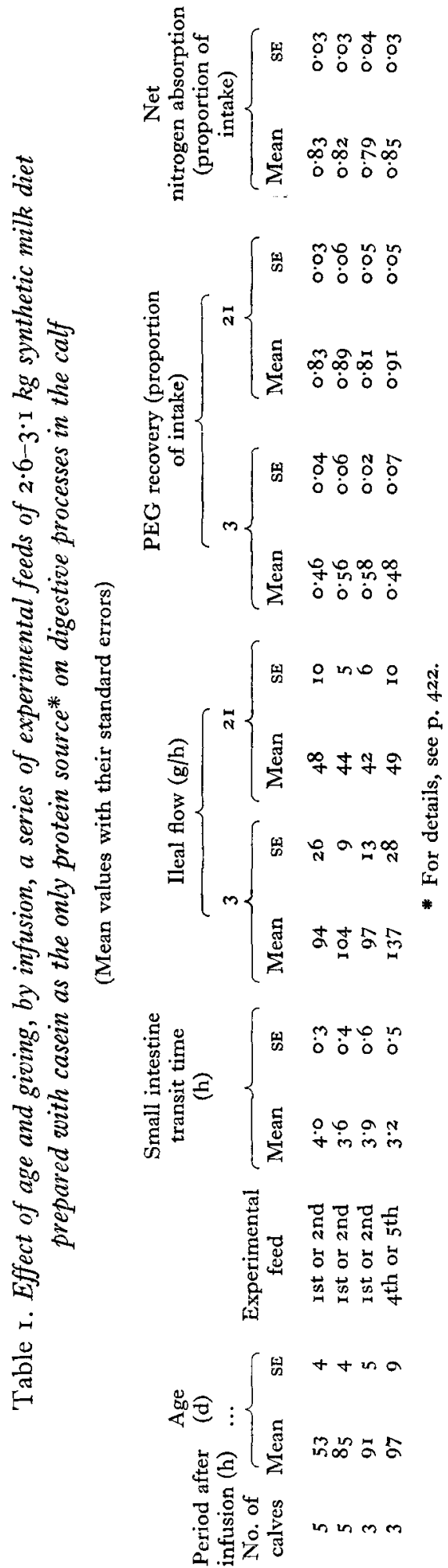


comparisons were made between whole milk and the diet containing casein (see Table 2) the general patterns of digesta flow were similar and values for SI transit time, 2I h PEG recovery, and net $\mathrm{N}$ absorption were not significantly different. However, to a small but significant extent, greater values were obtained for 3 and 2I $\mathrm{h}$ ileal flows and $3 \mathrm{~h}$ PEG recovery with the casein-based diet than with whole milk.

\section{Digesta flow and $N$ utilization after single experimental feeds of diets containing soya-bean products as the only protein source}

It was found earlier (Smith \& Sissons, 1975) that on the first or second occasion when a calf was given an experimental feed of a diet based on soya-bean flour that the rate of abomasal emptying was similar to that obtained when a milk-protein diet was given. Such a calf was considered to be unsensitized. When further experimental feeds of diets containing soya-bean flour were given there were marked changes and, after about four experimental feeds, a new and subsequently stable condition was established. The calf was then said to be sensitized. Changes of a similar kind were apparent in the present studies.

Unsensitized calves. Results for synthetic milk diets prepared with heated soya-bean flour (product B) as the only protein source compared with those for milk-proteinbased diets are given in Table 2. Values for 3 and $2 \mathrm{I} h$ ileal flows were somewhat greater and values for net $\mathrm{N}$ absorption were appreciably less for product B-based diets than for the milk-protein-based diets and, with one exception, these differences were significant. Values for 3 and 2I h PEG recoveries and SI transit time were not significantly different. One calf given the diet based on product A (lightly heated soya-bean flour) had values for most measurements which were not greatly different from those obtained from the calves given product B (fully heated soya-bean flour) although there was greatly reduced net $\mathrm{N}$ absorption (Table 2).

Sensitized calves. Patterns of flow of digesta from the distal ileum of calves given the product B-based diet for the first time (unsensitized) and the eighth time are shown in Fig. 2. The rates of development of the marked differences exemplified in Fig. 2 and of differences in PEG recovery and in net $\mathrm{N}$ absorption when a series of experimental feeds of the product B-based diet were given are shown in Fig. 3 .

It was apparent that SI transit time, $3 \mathrm{~h} \mathrm{PEG}$ recovery and net $\mathrm{N}$ absorption were higher and 3 and $2 \mathrm{I} h$ ileal flows were lower after a first or second experimental feed than after a fourth or subsequent experimental feed. Differences between results for Ist and $4^{\text {th }}$ experimental feeds and between ist and 7 th or 8th experimental feeds were significant (respective probability values in parentheses) for SI transit time $(P<0.05, P<0.01), 3$ h ileal flow $(P<0.05, P<0.05)$, 2 I h ileal flow $(P<0.01, P<0.05)$, 3 h $P$ EG recovery $(P<0.01, P<0.05)$ and net $\mathrm{N}$ absorption $(P<0.05, P<0.05)$.

There were no significant differences between any results for the $4^{\text {th }}$ and 7 th or 8th experimental feeds or between $2 \mathrm{I} \mathrm{h}$ PEG recovery results for any of the groups.

It appeared that after a calf had received four experimental feeds of the diet based on product $\mathrm{B}$ there was little further marked change when further experimental 
Vol. $3^{6}$

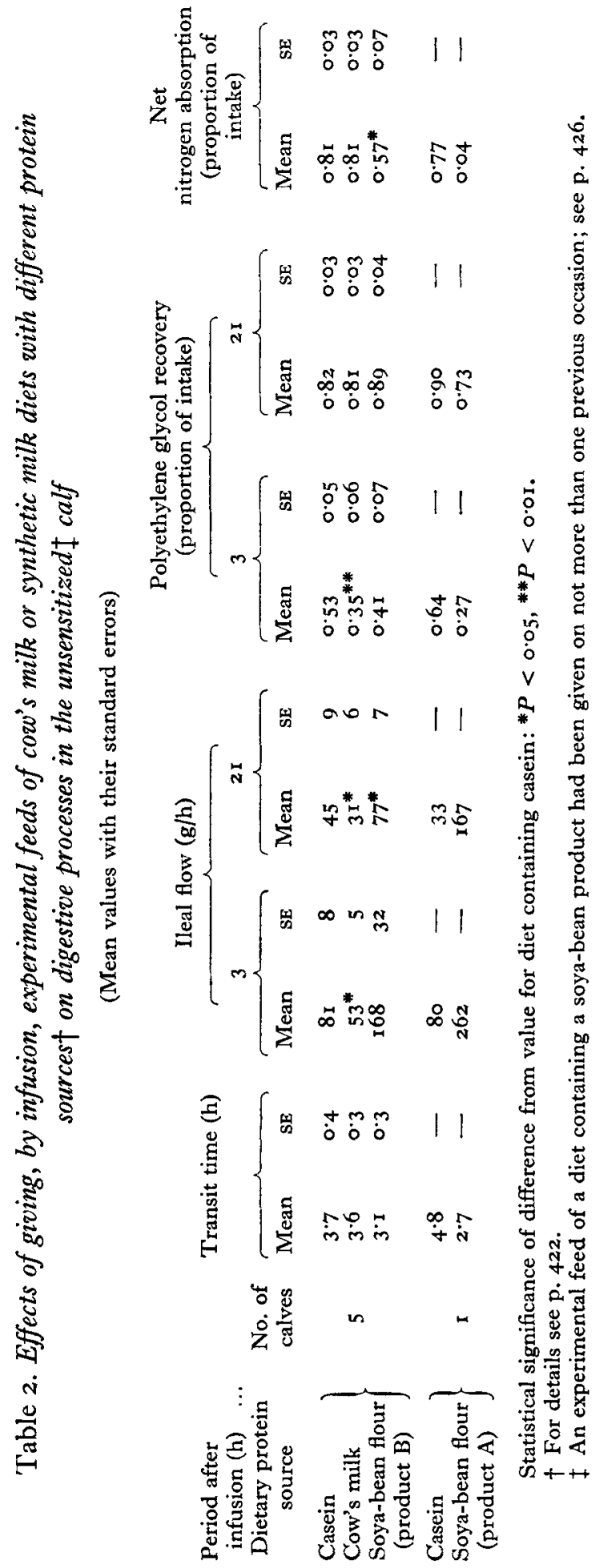




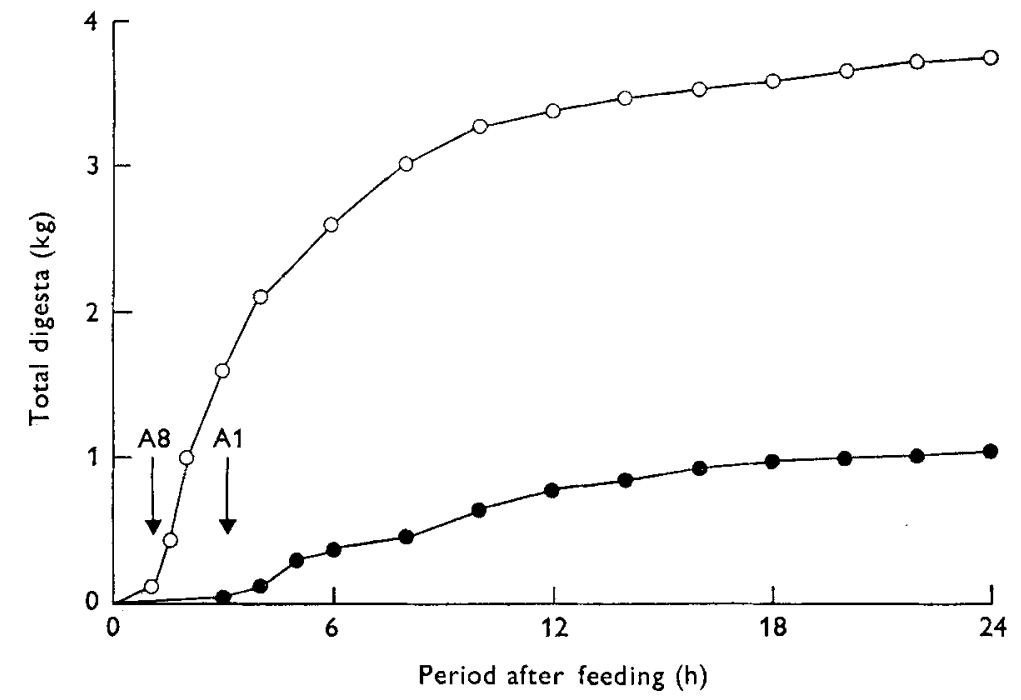

Fig. 2. Cumulative amounts of digesta (kg) leaving the distal ileum of a calf, between 48 and $76 \mathrm{~d}$ of age, after it was given, by infusion, experimental feeds of $2 \cdot 6 \mathrm{~kg}$ synthetic milk diet containing fully heated soya-bean flour as the only protein source (for details, see p. 422) for the first (O) and eighth (O) time. Phenol red, which was included in each experimental feed, appeared at the ileum at time interval $A_{1}$ and A8 after the first and eighth feeds respectively.

feeds were given. Thus in subsequent studies, calves given four or more experimental feeds of the product B-based diet were considered together as representing the sensitized state.

A number of experiments were carried out in which sensitized calves were given experimental feeds of different diets and the results in Table 3 indicate the comparative findings. For calves given the casein-based and the product B-based diets all measurements were markedly and significantly different, except $2 \mathrm{I}$ h PEG recovery. Calves given experimental feeds of the diet containing product $\mathrm{F}$ (isoelectric isolate of soya-bean protein) had values intermediate between those obtained for caseinand product B-based diets although differences from the values for the casein-based diet were significant only for net $\mathrm{N}$ absorption.

After receiving experimental feeds which contained product D (soya-bean concentrate prepared by alcohol extraction) the calves had significantly higher values for SI transit time, net $\mathrm{N}$ absorption and $3 \mathrm{~h}$ PEG recovery and significantly lower values for 3 and $2 \mathrm{r} \mathrm{h}$ ileal flows than calves given the product B-based diet. The results were, in fact, not significantly different from those obtained with the caseinbased diet. To check whether the results with the soya-bean concentrate were due to the removal, during its manufacture, of soluble but indigestible carbohydrate, a further experiment was carried out. Sucrose, which is not digestible by the calf (Siddons, I968) and is a major constituent, together with raffinose and stachyose, of the soluble carbohydrate in soya beans (Rackis, Honig, Sessa \& Steggerda, 1970), was added to the product D-based diet in an amount similar to the quantity of 

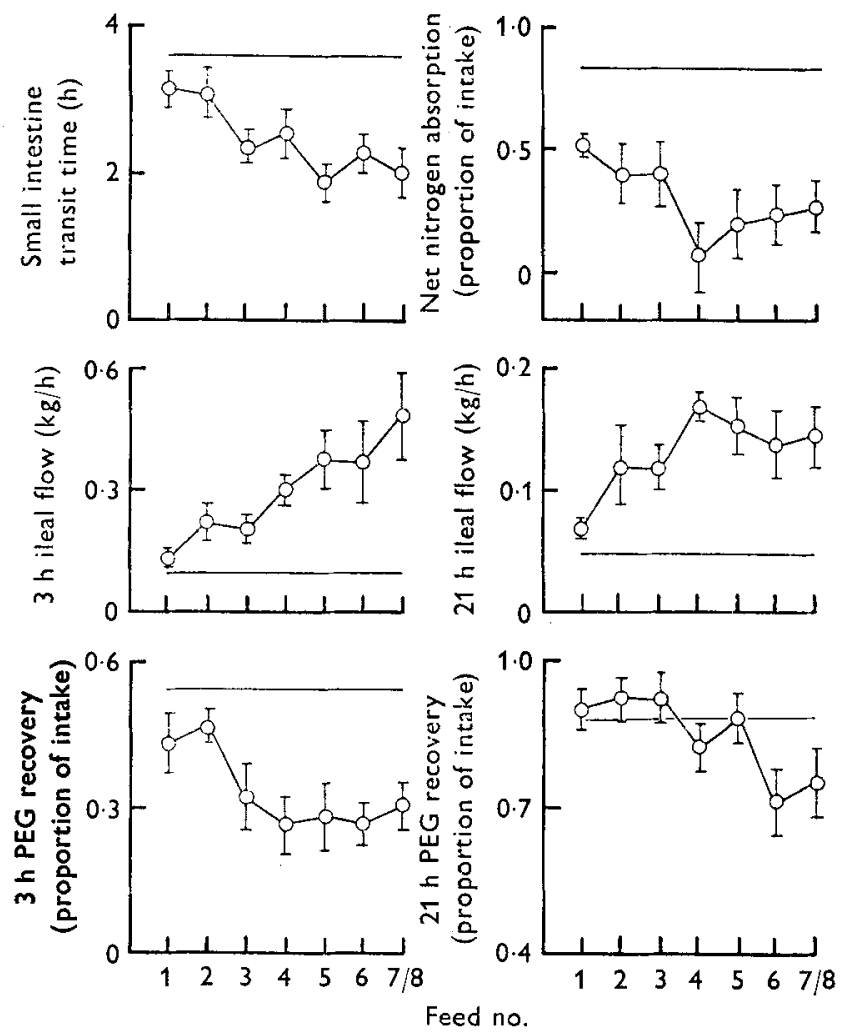

Fig. 3. Changes in digestive processes, determined at 3 and $2 \mathrm{r} h$, in calves given, by infusion, a series of experimental feeds of a synthetic milk diet containing fully heated soya-bean flour as the only protein source (for details see p. 422). Results are mean values for seven calves, with their standard errors indicated by vertical bars. The calves varied in age from 45 to $120 \mathrm{~d}$ and received $2 \cdot 6-3 \cdot \mathrm{Ig}$ synthetic milk diet/feed. Horizontal lines indicate mean values for the same calves when they were given experimental feeds of a diet containing casein during the period. PEG, polyethylene glycol.

soluble carbohydrate present in soya-bean flour. The addition had no appreciable effect on any of the measurements made.

In another experiment (Table 3) experimental feeds of the product B-based diet were compared with similar feeds of the product A (lightly heated soya-bean flour)based diet. Although not all the effects were significant the latter diet led to still lower SI transit times, lower net $\mathrm{N}$ absorption and higher ileal flows than the product B-based diet.

Diets based on products $\mathrm{E}$ and $\mathrm{G}$ were given in some experiments. The results (Table 3) were obtained from single calves and are mean values with their standard errors for replicate determinations for each calf. These diets led to disorders similar to those associated with the product B-based diet.

\section{Associations between different factors relating to disturbances in digestive function}

SI transit time and 21 $h$ ileal flow. Relationships between these factors obtained when different feeds were given are shown in Fig. 4. Variations in ileal flow found 


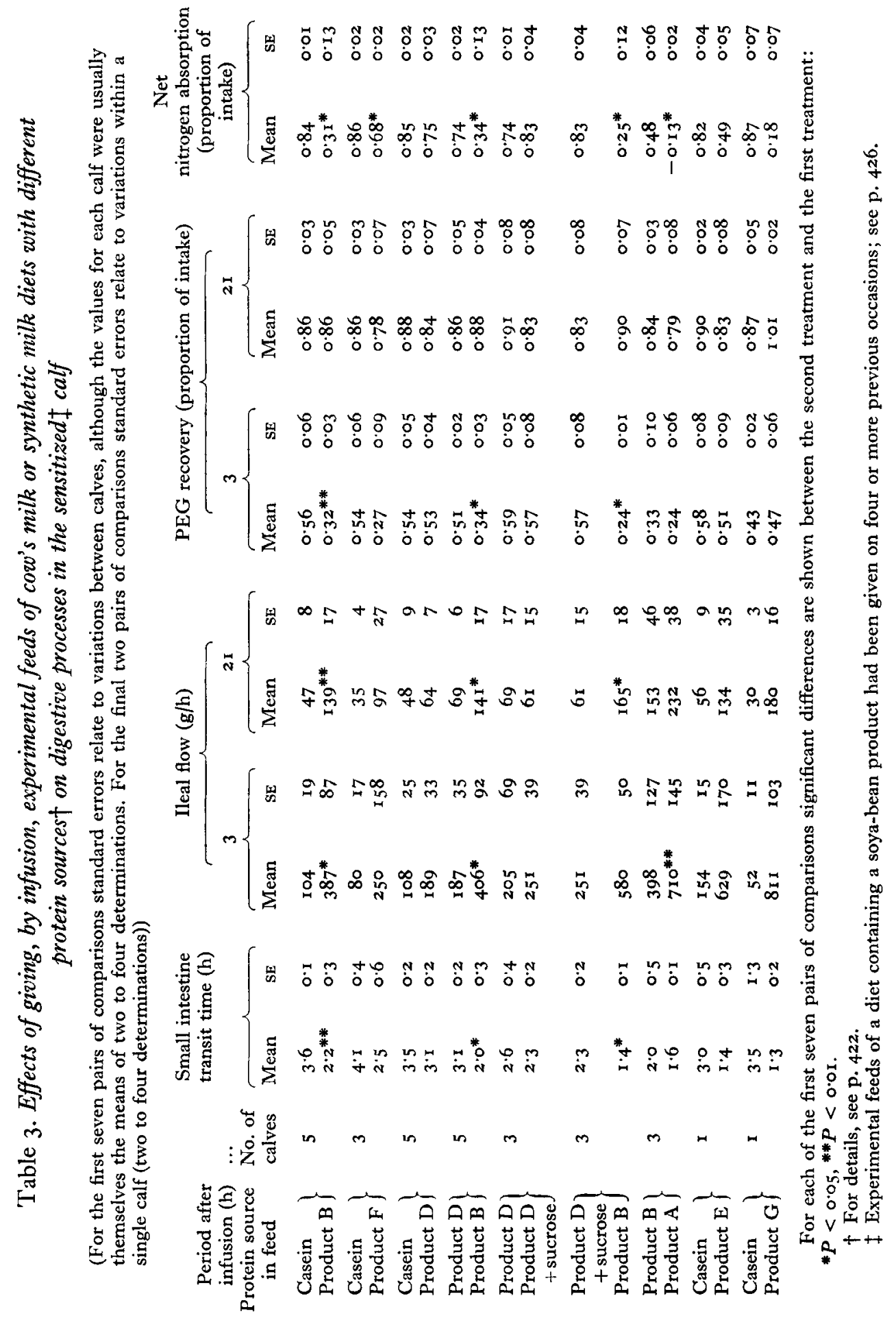




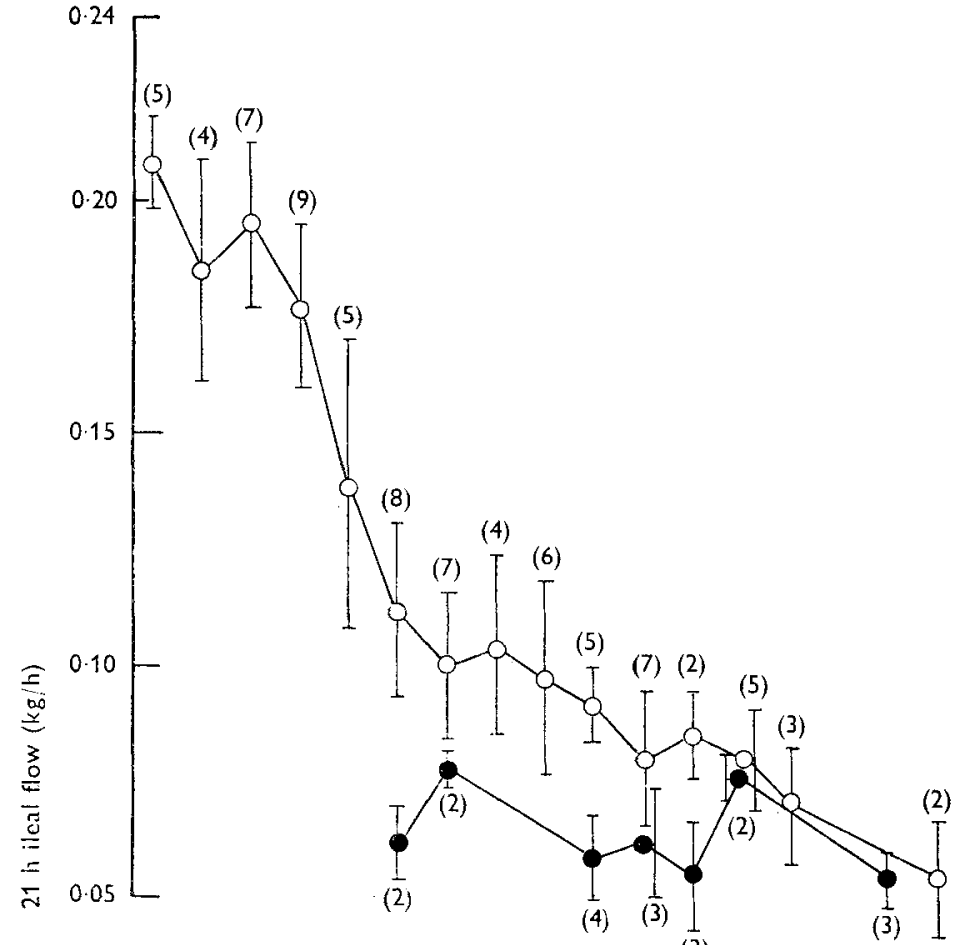

(3)

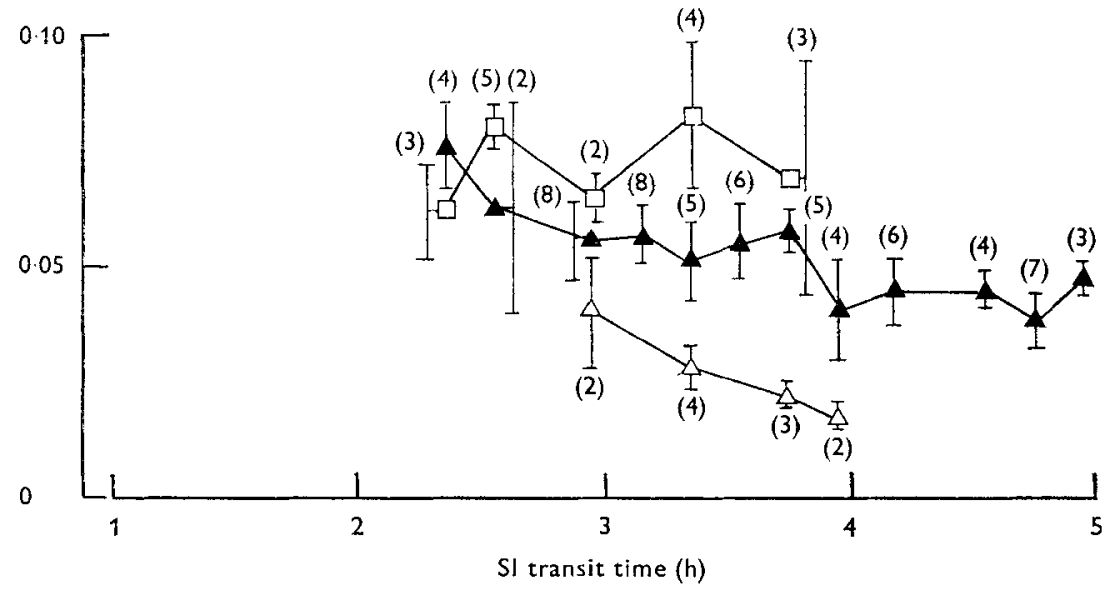

Fig. 4. Relationship between small intestine (SI) transit time (h) and ileal flow for $2 \mathrm{I} h$ $(\mathrm{kg} / \mathrm{h}$ ) (for details see p. 424) for calves given experimental feeds of cow's milk $(\Delta)$, or synthetic milk diets containing casein $(\mathbf{A})$, soya-bean concentrate, product $D(\square)$ or fully heated soya-bean flour $((\bullet)$, unsensitized calves and $(O)$, sensitized calves) as the only protein source (for details of diets, see p. 422). Values were included in the SI transit times values shown if they were within $\pm 0.1 \mathrm{~h}$ of these values. Mean ileal flow values are for the numbers of calves given in parentheses, with their standard errors, related to variation between calves, indicated by vertical bars. 


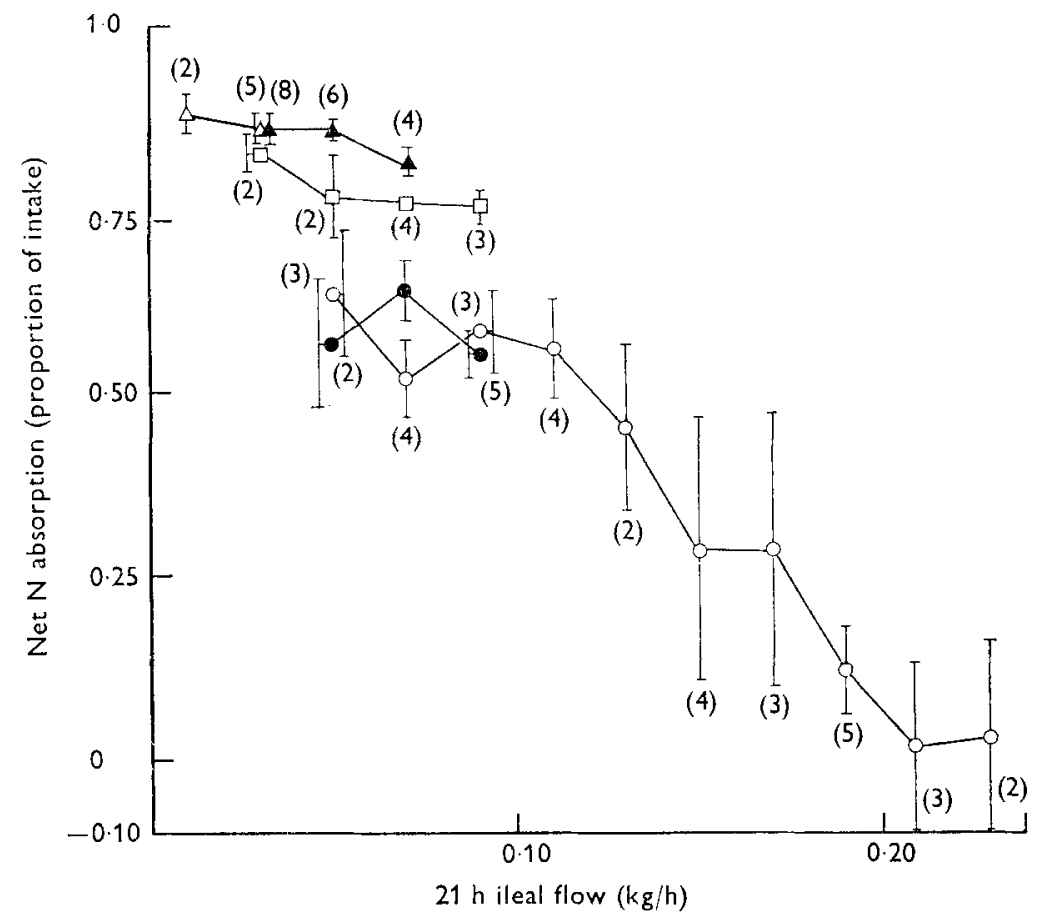

Fig. 5. Relationship between net nitrogen absorption (proportion of intake) and ileal flow for $2 \mathrm{I} \mathrm{h}(\mathrm{kg} / \mathrm{h})$ for calves given experimental feeds of cow's milk $(\triangle)$ or synthetic milk diets containing casein $(\mathbf{A})$, soya-bean concentrate, product $D(\square)$ or fully heated soya-bean flour ((O) unsensitized calves and $(O)$ sensitized calves) as the only protein source (for details of diets, see p. 422). Values were included in the ileal flow values shown if they were within $\pm 0.01 \mathrm{~kg} / \mathrm{h}$ of these values. Mean net $N$ absorption values are for the numbers of calves given in parentheses, with their standard errors, related to variation between calves, indicated by vertical bars.

between or within groups of unsensitized animals receiving cow's milk or diets containing casein, product $\mathrm{D}$ or product $\mathrm{B}$, did not appear to be associated with variations in SI transit time. For the sensitized calves receiving the product B-based diet, however, there was a strong and apparently curvilinear negative correlation which was particularly marked when SI transit time decreased to less than $2 \mathrm{~h}$.

Net $N$ absorption, SI transit time and 2I h ileal flow. The results for net $\mathrm{N}$ absorption by groups of unsensitized calves which received cow's milk or diets containing casein, product $\mathrm{D}$ or product $\mathrm{B}$ did not appear to be influenced appreciably, either between or within groups, by the variations found in ileal flow (Fig. 5). However, for sensitized calves which received the product B-based diet there was a strong negative correlation between $2 \mathrm{I} \mathrm{h}$ ileal flow and net $\mathrm{N}$ absorption when the former increased to more than $0 \cdot \mathrm{kg} / \mathrm{h}$. There was also a positive correlation between SI transit time and net $\mathrm{N}$ absorption (Fig. 6) for these calves.

3 h PEG recovery and other disturbances in gut function. The relatively low PEG recoveries found in the first $3 \mathrm{~h}$ after food residues reached the ileum in sensitized calves given the product B-based diet (Fig. 3) occurred despite low SI transit times and, presumably, were due mainly to inhibition of abomasal emptying (Smith 


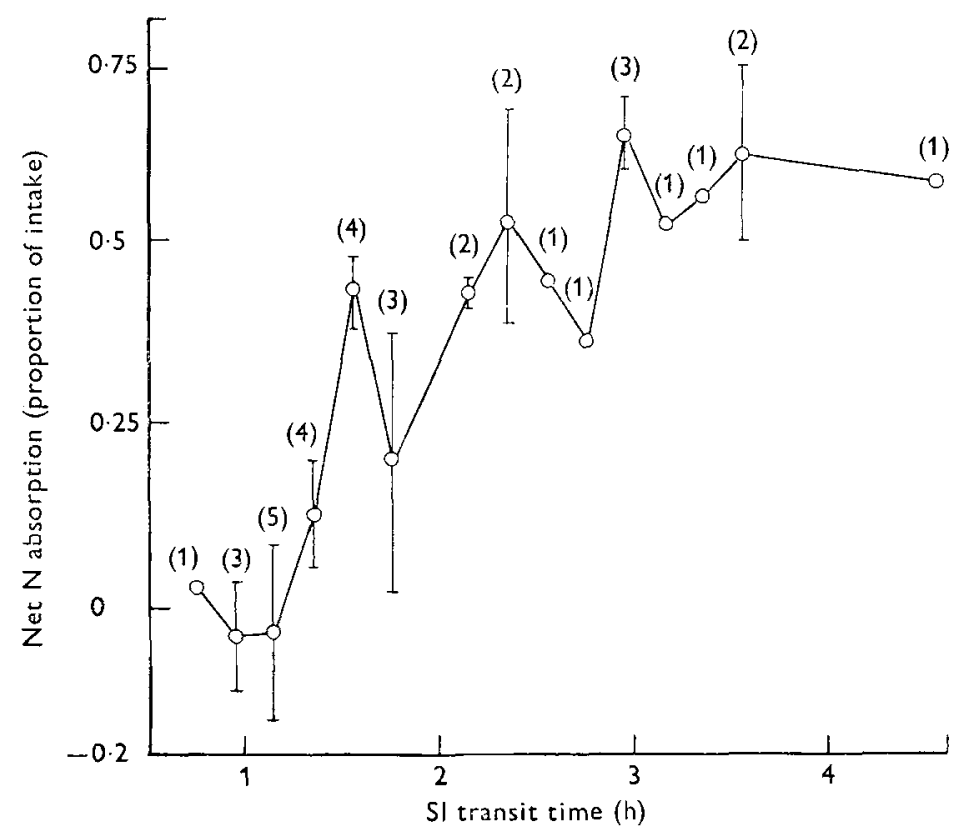

Fig. 6. Relationship between net nitrogen absorption (proportion of intake) and small intestine (SI) transit time (h) for sensitized calves given experimental feeds of fully heated soya-bean flour as the only protein source (for details of diets, see p. 422). Values were included in the SI transit times values shown if they were within $\pm 0.1 \mathrm{~h}$ of these values. Mean net $\mathrm{N}$ absorption values are for the numbers of calves given in parentheses, with their standard errors, related to variations between calves, indicated by vertical bars.

\& Sissons, I975). Subsequent recoveries of PEG (up to $2 \mathrm{I} h$ after the arrival of food residues at the duodenum) were largely unaffected by diet or sensitization.

Ileal flow and amounts of minerals in ileal contents. The results of preliminary experiments indicated that when experimental feeds of the product B-based diet were given to sensitized calves the varying rates of flow of ileal digesta obtained were accompanied by similarly varying rates of flow of $\mathrm{Na}$ and $\mathrm{K}$ in the digesta. In fact, total molar concentrations (sodium ions + potassium ions) were almost always higher in ileal digesta collected in the first $3 \mathrm{~h}$ after the arrival of food residues when a product B-based diet was infused than in the corresponding digesta sample obtained with cow's milk. For example, in four experiments with a sensitized calf which had very high rates of $3 \mathrm{~h}$ ileal flow $\left(25^{\circ}-690 \mathrm{~g} / \mathrm{h}\right)$ after the product B-based diet the values for $\mathrm{Na}^{+}$and $\mathrm{K}^{+}$were ${ }_{3}{ }^{\circ}-{ }_{45} \mathrm{mmol} / \mathrm{l}$. Corresponding values obtained after eight experiments in which cow's milk was infused were 50-100 mmol/1. It has been reported (Smith, I966) that the main factors responsible for determining the osmotic pressure of ileal digesta of calves given cow's milk or synthetic milk diets of similar composition are the concentrations of $\mathrm{Na}, \mathrm{K}$ and $\mathrm{Mg}$ and their associated anions in the digesta. Under conditions in which ileal digesta remain approximately isotonic with blood, the sum based on molar cation concentrations: $\mathrm{Na}^{+}+\mathrm{K}^{+}+\left(\mathrm{I} \cdot 5 \times\right.$ magnesium ions) remains fairly constant at $125^{-1} 5^{\circ} \mathrm{mmol} / \mathrm{l}$. A value within this range was obtained even for the very high ileal flow rates found 


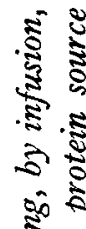

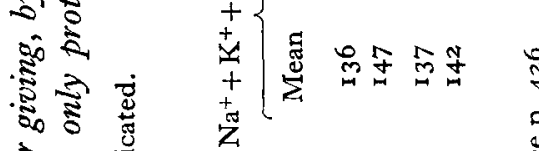

过

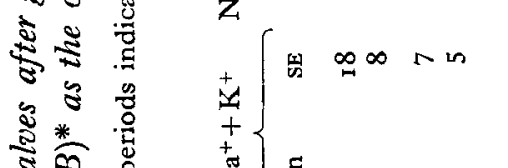

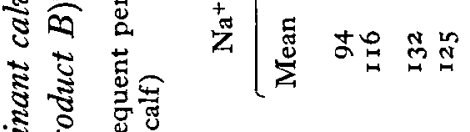

空 $\frac{0}{5}$

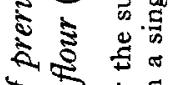

จई

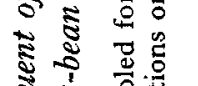

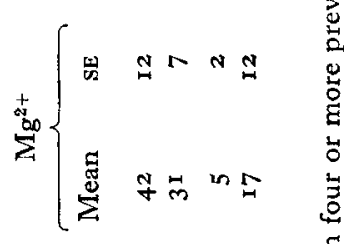

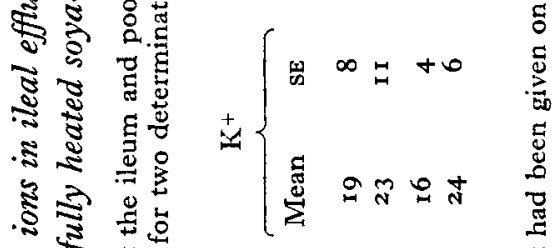

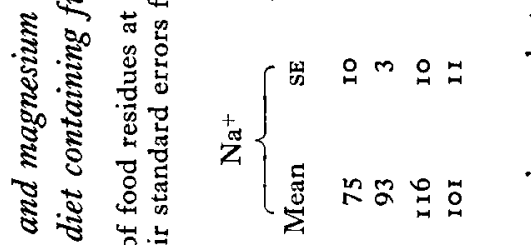

咅

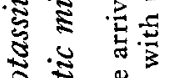

\&.

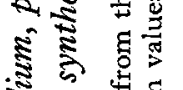

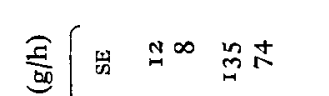

总

5 焉密 焉

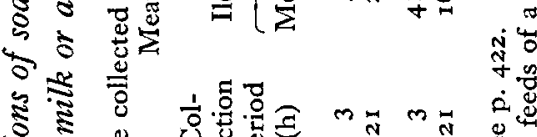

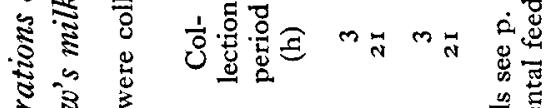

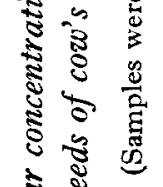

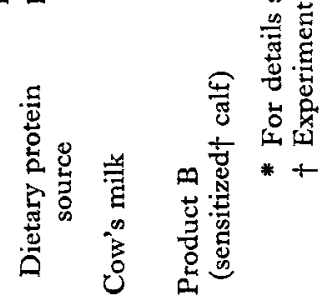


Table 5. Estimates of concentrations of viable bacteria of different types in samples of ileal digesta obtained after preruminant calves were given, by infusion, experimental feeds of cow's milk or a synthetic milk diet containing fully heated soya-bean flour (product B)* as the only protein source

(Samples were taken $2 \cdot 5-3 \cdot 0 \mathrm{~h}$ after residues from a feed arrived at the ileum. Mean values with their standard errors for two calves; values for the individual calves were themselves usually the means of two determinations)

\begin{tabular}{|c|c|c|c|c|c|c|c|c|}
\hline \multirow{3}{*}{$\begin{array}{l}\text { Dietary protein } \\
\text { source }\end{array}$} & & & \multicolumn{6}{|c|}{ Colony forming units $\left(\times 10^{-6} / \mathrm{g}\right)$} \\
\hline & \multicolumn{2}{|c|}{$\begin{array}{c}2 \text { i h Ileal flow } \\
(\mathrm{g} / \mathrm{h})\end{array}$} & \multicolumn{2}{|c|}{$\begin{array}{l}\text { MacConkey } \\
\text { agar§ }\end{array}$} & \multicolumn{2}{|c|}{ Acetate agar§ } & \multicolumn{2}{|c|}{ RCMI agar£ } \\
\hline & Mean & SE & Mean & $\mathrm{SE}$ & Mean & $\widehat{\mathrm{SE}}$ & Mean & $\mathrm{SE}$ \\
\hline Cow's milk & $3 \circ f$ & - & 25 & 2 & 26 & 18 & 250 & 200 \\
\hline $\begin{array}{l}\text { Product B } \\
\text { Unsensitized } \dagger \text { calves } \\
\text { Sensitized } \uparrow \text { calves }\end{array}$ & $\begin{array}{r}91 \\
179\end{array}$ & $\begin{array}{l}30 \\
\mathrm{r} 2\end{array}$ & $\begin{array}{l}2 \cdot 3 \\
1 \cdot 2\end{array}$ & $\begin{array}{l}0.2 \\
0.6\end{array}$ & $\begin{array}{r}13 \\
6\end{array}$ & $\begin{array}{l}4 \\
5\end{array}$ & $\begin{array}{l}59 \\
30\end{array}$ & $\begin{array}{l}23 \\
27\end{array}$ \\
\hline
\end{tabular}

* For details see p. 422.

+ Experimental feeds of a diet containing a soya-bean product had been given on not more than one previous occasion (unsensitized) or on four or more previous occasions (sensitized).

$\ddagger$ Assumed approximate value (see Table 2).

$\S$ For details of plating procedures, see below.

when a product B-based diet was administered to a sensitized calf (Table 4 ). It appeared that high flow-rates led to low $\mathrm{Mg}$ concentrations because of dilution and therefore, as isotonicity was maintained (Smith, I966) to relatively high concentrations of $\mathrm{Na}$ and $\mathrm{K}$.

Ileal flow and concentrations of viable bacteria in ileal contents. Samples of digesta from an ileal cannula were taken $2 \cdot 5-3.0 \mathrm{~h}$ after food residues from an experimental feed arrived at that site. The concentrations of colony-forming organisms in the samples were assessed using MacConkey agar for Escherichia coli, acetate agar (Rogosa, Mitchell \& Wiseman, 195I) for Lactobacilli, and RCM agar (Gibbs \& Hirsch, 1956) for total anaerobes. The results (Table 5) indicated that the high ileal flows obtained when sensitized calves were given the product B-based diet were not associated with an abnormal proliferation of bacteria in the ileum. In terms of colony-forming bacteria/g digesta, the numbers were, in fact, appreciably lower after experimental feeds of this diet than after those of cow's milk possibly due to the diluting effect of the greater digesta flow-rates.

\section{DISCUSSION}

Results of experiments with preruminant calves cannulated in the ileum (Smith, 1962, 1964; Mylrea, 1966a, b) have indicated that after a single feed of cow's milk the mean transit time of water-soluble digesta components from proximal duodenum to distal ileum is about $3.2 \mathrm{~h}$ and that between these sites there is about $80 \%$ net absorption of the dietary water. Present findings for transit time and volume of ileal flow for calves given cow's milk were consistent with these earlier findings. Efficiency of net absorption of dietary $\mathrm{N}$ up to the ileum (about $8 \mathrm{r} \%$ ) was lower 
than that reported for net $\mathrm{N}$ absorption by milk-fed calves in the small intestine (about 91 \%; Mylrea, $1966 b$ ) or in the whole gastrointestinal tract (about 91 \%; Roy, Gaston, Shillam, Thompson, Stobo \& Greatorex, 1964). The differences were undoubtedly due partly to the facts that different segments of the gastrointestinal tract were studied and ileal collections in the present studies were carried out for $24 \mathrm{~h}$ after a single experimental feed so that the contribution of endogenous $\mathrm{N}$ was exaggerated.

Differences in volume of ileal flow when a synthetic milk diet containing casein rather than cow's milk was given were small, although significant, and probably due mainly to variations in mineral composition. Some other differences in digesta movements and in nutrient absorption between experiments in which different diets were given can also be partly explained by the effect of known dietary constituents on digesta composition. Thus the low net digestibility of dietary $\mathrm{N}$ (Table 2) in the calf given product A (lightly heated soya-bean flour) was probably due to the considerable trypsin-inhibitor content of this product (Smith \& Sissons, 1975) and was consistent with the poor growth rate of calves given this type of soya-bean flour (Kakade, Thompson, Engelstad, Behrens \& Yoder, 1974). Similarly, the small differences in ileal flow and SI transit time after feeding a diet based on product B (fully heated soya-bean flour) for the first or second time rather than casein (Table 2) were probably due to the osmotic effects of poorly digested components in the soya-bean flour (Smith, I964, I966; Coombe, 1972).

The severe disturbances in movement of digesta and absorption of nutrients which developed when a calf was given a series of experimental feeds of the product B-based diet cannot, however, apparently be explained by a change in the properties of digesta entering the duodenum. They appeared rather to be due to a change in the response of the calf. The various disturbances were apparently interrelated (Figs 4, 5 and 6) and possibly all stemmed from a reduced SI transit time which, once below a critical point, may have led to decreased nutrient absorption which, in turn, led to increased ileal flow, largely because of osmotic effects. Like the previously reported changes in abomasal function (Smith \& Sissons, 1975) it appeared that the disorders were caused by sensitization to a factor in the soya-bean flour, which induced an allergic response in the gastrointestinal tract. The disorders indicate some similarity to those found in certain human subjects sensitive to wheat gluten. However, no counterpart to the changes in structure of the intestinal wall characteristic of this disorder (Rubin, Brandborg, Flick, Phelps, Parmentier \& van Niel, I962) or to the similar changes reported in the gut wall of one human patient sensitive to soya-bean products (Ament \& Rubin, r972) were detected on histological examination of the intestine of two calves which had marked disturbances of digestive function after a series of eight to twelve experimental feeds of the product B-based diet (Smith \& Sissons, unpublished results). Evidence of a gross intestinal disorder in two calves after they had received twelve to fifteen product B-based feeds was provided, however, by the occurrence of material in ileal contents which appeared to consist of partially digested blood clots (Smith \& Sissons, unpublished results). 
It appeared that bacterial proliferation was not responsible for the disorders which we found, as the numbers of bacteria in ileal contents were no greater in calves with increased ileal flow-rates after receiving the product B-based diet than after receiving cow's milk. Concentrations of $E$. coli were approximately the same as those reported for younger healthy calves which had received colostrum $(\mathrm{H}$. W. Smith, 1962; Contrepois \& Gouet, 1973). It should, however, be borne in mind that all the present animals received $0.4 \mathrm{~g}$ aureomycin/d when they were not receiving experimental feeds.

As the toxic factor is present in product B it apparently survives commercial heat treatment which removes most of the trypsin inhibitor and haemagglutinin activity (Wolf, 1967). Its activity in different soya-bean products was not apparently related to their contents of poorly-digestible water-soluble carbohydrates.

It is not known whether the commercial extraction of soya-bean meal with hot aqueous ethanol (to produce product $D$ ) which apparently removes the toxic factor, does so by extracting it or destroying it. Its removal, however, may account for the fact that calves given diets containing large proportions of their protein in the form of products similar to product D have good growth (Gorrill \& Thomas, 1967 ; Nitsan, Volcani, Gordin \& Hasdai, 197I) while calves given diets in which heated soya-bean flour forms a major protein source generally do not (Gorrill \& Thomas, 1967; Colvin \& Ramsey, 1968; Nitsan, Volcani, Hasdai \& Gordin, 1972; Paruelle, Toullec, Frantzen \& Mathieu, 1972; Kwiatkowska, 1973).

Treatment of heated flours in different ways, notably with acid or alkali, has led to products of variable feeding value (Colvin \& Ramsey, 1968, 1969; Kakade, Simons \& Liener, 1971; Ramsey \& Willard, 1975). In preliminary experiments with commercial alkali- and acid-treated products, marked disturbances in digesta flow were found and mean values for net $\mathrm{N}$ absorption between mouth and distal ileum of only $0.5^{1}$ and 0.18 respectively were obtained (Smith \& Sissons, unpublished results). The suggestion of Willard \& Ramsey (1974) that the further removal of the small amounts of trypsin inhibitor in heated soya-bean flour by acid or alkali treatment is responsible for improving the nutritional value of heated soya-bean flour is not supported by our finding that product $\mathrm{D}$, which we found to cause little digestive disturbance, contained as much trypsin inhibitor (see Table I of Smith \& Sissons, 1975) as product B, which caused serious disturbance.

The authors thank Dr H. Buttle and Mr S. Watson for carrying out all surgical operations, Dr M. E. Sharpe for the bacterial counts, Dr D. Hewitt for statistical advice, Mrs S. J. Askew for assistance with the animal experiments and Mr A. Turvey for preparing slides of intestine. They also thank Swift \& Co., Chicago, Ill., USA; The British Arkady Co. Ltd, Manchester, UK; Central Soya, Chicago, Ill., USA; and Hayes (Ashdod) Ltd, Israel, for gifts of soya-bean flours or concentrates. 


\section{REFERENCES}

Ament, M. E. \& Rubin, C. E. (1972). Gastroenterology 62, 227.

Ash, R. W. (1962). Anim. Prod. 4, 309.

Colvin, B. M. \& Ramsey, H. A. (1968). ๆ. Dairy Sci. 5I, 898.

Colvin, B. M. \& Ramsey, H. A. (1969). F. Dairy Sci. 52, 270.

Contrepois, M. \& Gouet, Ph. (1973). Ann. Rech. vétér. 4, r6r.

Coombe, N. B. (1972). Carbohydrate digestion and absorption in the preruminant calf. $\mathrm{PhD}$ Thesis, University of Reading.

Gibbs, B. M. \& Hirsch, A. (1956). भ. appl. Bact. 19, 129.

Gorrill, A. D. L. \& Thomas, J. W. (1967). Y. Nutr. $92,215$.

Kakade, M. L., Simons, N. R. \& Liener, I. E. (1971). F. Dairy Sci. 54, 1705.

Kakade, M. L., Thompson, R. M., Engelstad, W. E., Behrens, G. C. \& Yoder, R. D. (1974). f. Dairy Sci. 57,65 .

Kwiatkowska, A. (1973). Pr. Mater. Zootech. 3, 63.

Mylrea, P. J. (1966a). Res. vet. Sci. 7, 333.

Mylrea, P. J. (1966b). Res. vet. Sci. 7, 394.

Nitsan, Z., Volcani, R., Gordin, S. \& Hasdai, A. (1971). F. Dairy Sci. 54, 294.

Nitsan, Z., Volcani, R., Hasdai, A. \& Gordin, S. (1972). F. Dairy Sci. 55, 8 Ir.

Paruelle, J.-L., Toullec, R., Frantzen, J.-F. \& Mathieu, C.-M. (1972). Annls Zootech. 21, 319.

Rackis, J. J., Honig, D. H., Sessa, D. J. \& Steggerda, F. R. (1970). F. agric. Fd Chem. 18, 977.

Ramsey, H. A. \& Willard, T. R. (1975). F. Dairy Sci. 58, 436.

Rogosa, M., Mitchell, J. A. \& Wiseman, R. T. (195 I). F. dent. Res. 30, 682.

Roy, J. H. B., Gaston, H. J., Shillam, K. W. G., Thompson, S. Y., Stobo, I. J. F. \& Greatorex, J. C. (1964). Br. F. Nutr. 18, 467 .

Rubin, C. E., Brandborg, L. L., Flick, A. L., Phelps, P., Parmentier, C. \& van Niel, S. (1962). Gastroenterology 43, $62 \mathrm{I}$.

Siddons, R. C. (r968). Biochem. F. 108, 839.

Smith, H. W. (1962). $\mathcal{F}$. Path. Bact. 84, 147.

Smith, R. H. (1958). Nature, Lond. 182, 260.

Smith, R. H. (1962). Biochem. F. 83, 5 r.

Smith, R. H. (1964). F. Physiol., Lond. 172, 305.

Smith, R. H. (1966). F. Physiol., Lond. 183, 532.

Smith, R. H. \& McAllan, A. B. (1966). Br. Y. Nutr. 20, 703.

Smith, R. H. \& Sissons, J. W. (1975). Br. Y. Nutr. 33, 329 .

Tagari, H. \& Roy, J. H. B. (1969). Br. Y. Nutr. 23, 763 .

Willard, T. R. \& Ramsey, H. A. (1974). Fedn Proc. Fedn Am. Socs exp. Biol. 33, 707.

Wolf, W. J. (r g67). Proc. int. Conf. Soybean Protein Foods, Illinois, r966, p. 112.

Technicon Instruments Co. Ltd (1967). Technicon Methodology Sheet N-3b. Basingstoke: Technicon Instruments Co. Ltd. 